\title{
Role of Communications and Working Relationships to Organizational Culture of Fast Food Industry in Nueva Ecija
}

\author{
Rowena B. Abat
}

Instructor, College of Management and Business Technology, Nueva Ecija University of Science and Technology, Philippines

\begin{abstract}
The workplace's organizational culture governs the way the views, principles and values of the workers, as well as those outside the organization are treated.This study described the organizational culture in the fast food industry in terms of communication channels in the organization, relationship with the supervisor, and employee to employee relationship. It also determined the level of importance of communication channels in the organization, relationship with the supervisor, and employee to employee relationship to organizational culture. The descriptive method of research was used in this study. The researcher distributed survey questionnaires which adapted Likert-scale type responses to a total of 113 employees (46 males and 67 females) of fast food industry. Gathered data were analyzed through descriptive statistics such as mean and standard deviation. The researcher concluded that in an organizational culture in the fast food industry it should consider the importance of how the communication channels work, the relationship of the employees with their immediate supervisors, and the employee to employee relationship. Employee to employee relationship is very important to be monitored in the group since employees make a bigger part of the organization. Superiors should be accessible to all members of the organization to lend sympathetic ears in cases of queries of the employees. My immediate supervisor encourages my suggestions for improvement. Activities must be done to promote healthy culture at the workplace. Thus, it is recommended for any organization, specifically fast food industries, to develop a program and activities to enhance and strengthen the communication channels, relationship with immediate the supervisor and the employee to employee relationship. This program and activities will help promote healthy culture at the workplace.
\end{abstract}

Keywords- Organizational Culture, Organization, Communication, Working Relationship, Employee to Employer, Employer to Employee.

\section{INTRODUCTION}

The workplace's organizational culture governs the way the views, principles and values of the workers, as well as those outside the organization are treated. Healthy organizations need to optimize human resources to reach their goals; align their services and motivate their workers (Santos \& Nocum, 2020).

Organizational culture and cultural change can be used as a way of planning the development environment, as a measure for determining whether or not a transformation has actually occurred, and as a means of achieving the desired results of progress (Keup et al., 2001).Organizational culture helps its participants to view situations in a similar way and offers the continuity that an organization needs in an ever-changing world to succeed (Is, 2006).

An employee has many preconceived notions of how their organization can communicate with them, and communication can be one of them, so a difference could be generated if their organization fails to meet their communication standards (Hayase, 2009). It is important to influence their job actions and behaviors by explaining and encouraging the corporate vision to superiors, and by gaining their appreciation of the vision (Tsai, 2011).

Employees with different types of culture prioritize various aspects of their pursuit of organizational sustainability, 
ranging from an emphasis on internal staff growth, resource efficiency, environmental protection or stakeholder engagement (Linnenluecke \& Griffiths, 2010).

In view of the foregoing insights, the researcher would like to assess the role of communication and working environment to organizational culture of fast food industry in Nueva Ecija.

\section{CONCEPTUAL FRAMEWORK}

Corporate environment and organizational culture are two alternate ways that conceptualize how people experience and characterize their job environments (including not just corporations but schools and governments as well) (Schneider et al., 2013).

Organizational culture is the pattern of common values and beliefs that helps people understand how the organization works and thus provides them with behavioral norms within the organization (Lund, 2003).

Leadership and organizational culture have a positive effect on employee satisfaction but lack significant effect, however it can create dramatically positive effects on employee satisfaction through the activity of the learning organization (Chang \& Lee, 2007).

\section{OBJECTIVES OF THE STUDY}

This studydescribed the organizational culture in the fast food industry in terms of communication channels in the organization, relationship with the supervisor, and employee to employee relationship. It also determined the level of importance of communication channels in the organization, relationship with the supervisor, and employee to employee relationship to organizational culture.

\section{METHODOLOGY}

The descriptive method of research was used in this study as it is often combined with the measurement, classification, interpretation, and evaluation of comparison and contrast. (Willis et al., 2016). The researcher distributed survey questionnaires which adapted Likert-scale type responses (Vagias, 2006) to a total of 113 employees (46 males and 67 females) of fast food industry.Gathered data were analyzed through descriptive statistics such as mean and standard deviation.

\section{RESULTS AND DISCUSSIONS}

Table 1. Communication Channels in the Organization

\begin{tabular}{|c|c|c|c|}
\hline & $\begin{array}{c}\text { Mean } \\
(X)\end{array}$ & $\begin{array}{c}\text { Standard Deviation } \\
(S D)\end{array}$ & $\begin{array}{c}\text { Verbal Interpretation } \\
\text { (VI) }\end{array}$ \\
\hline $\begin{array}{l}\text { 1. The management clearly passes on necessary } \\
\text { information to all employees. }\end{array}$ & 3.25 & 0.756 & Strongly Agree \\
\hline $\begin{array}{l}\text { 2. Employees have the freedom to share their ideas and } \\
\text { concepts on an open forum. }\end{array}$ & 3.13 & 0.518 & Agree \\
\hline $\begin{array}{l}\text { 3. Feedbacks from employees are accepted by the } \\
\text { management }\end{array}$ & 3.25 & 0.916 & Strongly Agree \\
\hline 4. Communication between departments is very open. & 2.75 & 0.886 & Agree \\
\hline $\begin{array}{l}\text { 5. Superiors are accessible to all members of the } \\
\text { organization to lend sympathetic ears in cases of queries. }\end{array}$ & 3.38 & 0.756 & Strongly Agree \\
\hline $\begin{array}{l}\text { 6. Effective communication increases the morale among } \\
\text { the members of }\end{array}$ & 2.88 & 0.518 & Agree \\
\hline
\end{tabular}




\begin{tabular}{|r|c|c|c|c|}
\hline $\begin{array}{l}\text { 7. } \\
\text { Management actively solicits input from employees } \\
\text { before major decisions are made. }\end{array}$ & 3.13 & 0.535 & Agree \\
\hline 8. The department is open to suggestions. & 2.88 & 0.835 & Agree \\
\hline & Average & $\mathbf{3 . 0 8}$ & $\mathbf{0 . 8 3 0}$ & Agree \\
\hline
\end{tabular}

\section{Legend Verbal Interpretation}

$\begin{array}{cccc}3.25-4.00 & \text { Strongly Agree } & 1.75-2.49 & \text { Disagree } \\ 2.50-3.24 & \text { Agree } & 1.00-1.74 & \text { Strongly Disagree }\end{array}$

Table 1 shows how the communication channels work in the organizational culture of fast food industries. Based on the result, the communication channels in the organization got an average mean of 3.08, a standard deviation of 0.830 , and with a verbal interpretation of 'agree'. This is further supported by some of its indicators. Items 5, 3, and 1 got the highest means among other indicators. Superiors are accessible to all members of the organization to lend sympathetic ears in cases of queries $(X=3.38, S D$ $=0.756, V I=$ 'strongly agree'). Feedbacks from employees are accepted by the management $(X=3.25, S D=0.916, V I=$ 'strongly agree'). The management clearly passes on necessary information to all employees $(X=3.25, S D=0.756, V I=$ 'strongly agree'). Though, it is noticeable that Item 8 got the lowest mean of 2.88 , standard deviation of 0.835 , and with verbal interpretation of 'agree'.

\begin{tabular}{|c|c|c|c|}
\hline & $\begin{array}{c}\text { Mean } \\
(X)\end{array}$ & $\begin{array}{c}\text { Standard Deviation } \\
(S D)\end{array}$ & $\begin{array}{c}\text { Verbal Interpretation } \\
(\text { VI })\end{array}$ \\
\hline $\begin{array}{l}\text { 1. My immediate supervisor respects me as an } \\
\text { individual. }\end{array}$ & 3.25 & 0.886 & Strongly Agree \\
\hline 2. My supervisor is open to constructive criticism. & 2.63 & 0.916 & Agree \\
\hline $\begin{array}{l}\text { 3. My immediate supervisor listens to what I have to } \\
\text { say. }\end{array}$ & 2.88 & 0.991 & Agree \\
\hline 4. My supervisor deals fairly with me. & 3.13 & 0.926 & Agree \\
\hline $\begin{array}{l}\text { 5. My immediate supervisor encourages my suggestions } \\
\text { for improvement. }\end{array}$ & 3.59 & 0.518 & Strongly Agree \\
\hline $\begin{array}{l}\text { 6. Effective interpersonal skills are important to all } \\
\text { immediate supervisors. }\end{array}$ & 3.38 & 0.744 & Strongly Agree \\
\hline $\begin{array}{l}\text { 7. Our supervisors have done a good job of translating } \\
\text { the organization's objectives into meaningful } \\
\text { assignments of the employees. }\end{array}$ & 3.29 & 0.707 & Strongly Agree \\
\hline 8. The department is open to suggestions. & 2.88 & 0.835 & Agree \\
\hline Average & 3.13 & 0.815 & Agree \\
\hline
\end{tabular}

\section{Legend Verbal Interpretation}

$\begin{array}{cccc}3.25-4.00 & \text { Strongly Agree } & 1.75-2.49 & \text { Disagree } \\ 2.50-3.24 & \text { Agree } & 1.00-1.74 & \text { Strongly Disagree }\end{array}$


Table 2 shows the relationship of the crew with their supervisor in the organizational culture of fast food industries. Based on the result, the relationship with the supervisor got an average mean of 3.13, a standard deviation of 0.815 , and with verbal interpretation of 'agree'. This further presents by some of its indicators. Items 5, 6, 7, and 1 got the highest means among other indicators. My immediate supervisor encourages my suggestions for improvement. ( $X$
$=3.59 S D=0.518, V I=$ 'strongly agree'Effective interpersonal skills are important to all immediate supervisors ( $X=3.38, S D=0.744, V I=$ 'strongly agree'). Our supervisors have done a good job of translating the organization's objectives into meaningful assignments of the employees. ( $X=3.29, S D=0.707, V I=$ 'strongly agree'). My immediate supervisor respects me as an individual. $(X=$ $3.25, S D=0.886, V I=$ 'strongly agree').

\begin{tabular}{|ll|c|c|c|}
\hline \multicolumn{4}{|c|}{ Table 3. Employee to Employee Relationship } \\
\hline & $\begin{array}{c}\text { Mean } \\
(\boldsymbol{X})\end{array}$ & $\begin{array}{c}\text { Standard Deviation } \\
(\text { SD })\end{array}$ & $\begin{array}{c}\text { Verbal Interpretation } \\
(\text { VI })\end{array}$ \\
\hline 1. & Employees avoid conflicts at the workplace. & 3.38 & 0.916 & Strongly Agree \\
\hline 2. & Everyone treats one another like a family member. & 2.78 & 0.035 & Agree \\
\hline 3. & All employees accept challenges with a smile. & 3.19 & 0.756 & Agree \\
\hline 4. & $\begin{array}{l}\text { Helping one another is the foundation of the group's } \\
\text { bonding. }\end{array}$ & 2.88 & 0.991 & Strongly Agree \\
\hline $\begin{array}{l}\text { 5. } \\
\text { Every employee remains calm and understanding when } \\
\text { problems arise in the group. }\end{array}$ & 3.35 & 0.706 & Strongly Agree \\
\hline 6. & Employees avoid controversies and rumors & 3.28 & 0.707 & Agree \\
\hline 7. & One always works with open mind. & 2.95 & 0.886 & Strongly Agree \\
\hline 8. & $\begin{array}{l}\text { Employees set activities to promote healthy culture at the } \\
\text { work place }\end{array}$ & 3.52 & 0.707 & Agree \\
\hline
\end{tabular}

\section{Legend}

$$
3.25-4.00
$$$$
2.50-3.24
$$

\section{Verbal Interpretation}

$\begin{array}{cc}\text { Strongly Agree } & 1.75-2.49 \\ \text { Agree } & 1.00-1.74\end{array}$

\section{Disagree}

Strongly Disagree
Table 3 shows the employee to employee relationship of the crew in relation to the organizational culture of fast food industries. Based on the result, the communication channels got an average mean of 3.17 , a standard deviation of 0.840 , and with verbal interpretation of 'agree'. This further presents by some of its indicators. Items 8, 1, 5, and 6 got the highest means among other indicators. Employees set activities to promote healthy culture at the work place $(X=$
3.52, $S D=0.707, V I=$ 'strongly agree'.) Employees avoid conflicts at the workplace $(X=3.38, S D=0.916, V I=$ 'strongly agree'). Every employee remains calm and understanding when problems arise in the group $(X=3.35$, $S D=0.706, V I=$ 'strongly agree'). Employees avoid controversies and rumors $(X=3.32, S D=0.707, V I=$ 'strongly agree'). 


\begin{tabular}{|c|c|c|c|}
\hline \multicolumn{4}{|c|}{ Table 4. Summary of the Organizational Culture in the Fast Food Industry } \\
\hline & $\begin{array}{c}\text { Mean } \\
(\boldsymbol{X})\end{array}$ & $\begin{array}{c}\text { Verbal Interpretation } \\
(\boldsymbol{V I}))\end{array}$ & $\begin{array}{c}\text { Level Of } \\
\text { Importance }\end{array}$ \\
\hline Communication Channels in the Organization & 3.08 & Agree & Moderately Important \\
\hline Relationship with the Supervisor & 3.13 & Agree & Moderately Important \\
\hline Employee to Employee Relationship & 3.17 & Agree & Moderately Important \\
\hline
\end{tabular}

\section{Legend}

$3.25-4.00$

$2.50-3.24$

$1.75-2.49$

$1.00-1.74$
Verbal Interpretation

Strongly Agree

Agree

Disagree

Strongly Disagree
Level of Importance

Very Important

Moderately

Important

Somewhat

Important

Slightly Important
Table 4 presents the summary of the organizational culture in the fast food industry and their level of importance. Based on the result, the organizational culture of fast food industry may be described in terms of communication channels in the organization $(X=3.08, V I=$ 'agree'), relationship with the supervisor $(X=3.13, V I=$ 'agree'), and employee to employee relationship $(X=3.17, V I=$ 'agree'). Among these aspects, employee to employee relationship got the highest mean. However, all these aspects were found to be equally and moderately important in the organizational culture in the fast food industry.

\section{CONCLUSIONS AND RECOMMENDATIONS}

The researcher concluded that in an organizational culture in the fast food industry it should consider the importance of how the communication channels work, the relationship of the employees with their immediate supervisors, and the employee to employee relationship. Employee to employee relationship is very important to be monitored in the group since employees make a bigger part of the organization. Superiors should be accessible to all members of the organization to lend sympathetic ears in cases of queries of the employees. My immediate supervisor encourages my suggestions for improvement. Activities must be done to promote healthy culture at the workplace.

Thus, it is recommended for any organization, specifically fast food industries, to develop a program and activities to enhance and strengthen the communication channels, relationship with immediate the supervisor and the employee to employee relationship. This program and activities will help promote healthy culture at the workplace.

\section{REFERENCES}

[1] Chang, S. C., \& Lee, M. S. (2007). A study on relationship among leadership, organizational culture, the operation of learning organization and employees' job satisfaction. The learning organization.

[2] Creswell, J. W. (2014). A concise introduction to mixed methods research. SAGE publications.

[3] Hayase, L. K. T. (2009). Internal communication in organizations and employee engagement.

[4] Is, W. O. C. (2006). "That's the Way We Do Things Around Here": An Overview of Organizational Culture. Electronic Journal of Academic and special librarianship, 7(1).

[5] Linnenluecke, M. K., \& Griffiths, A. (2010). Corporate sustainability and organizational culture. Journal of world business, 45(4), 357-366.

[6] Lund, D. B. (2003). Organizational culture and job satisfaction. Journal of business \& industrial marketing.

[7] Keup, J. R., Walker, A. A., Astin, H. S., \& Lindholm, J. A. (2001). Organizational Culture and Institutional Transformation. ERIC Digest.

[8] Santos, K. E. S., \& Nocum, C. L. R. (2020). Organizational Condition of Private Schools and Colleges in Nueva Ecija. Open Access Library Journal, 7(2), 1-8. 
[9] Schneider, B., Ehrhart, M. G., \& Macey, W. H. (2013). Organizational climate and culture. Annual review of psychology, 64, 361-388.

[10] Tsai, Y. (2011). Relationship between organizational culture, leadership behavior and job satisfaction. BMC health services research, 11(1), 98.

[11] Vagias, W. M. (2006). Likert-type scale response anchors. clemson international institute for tourism. \& Research Development, Department of Parks, Recreation and Tourism Management, Clemson University. 